\title{
Impact of the 13-valent pneumococcal conjugate vaccine on the incidence of consolidated pneumonia in children younger than 5 years old in Pilar, Buenos Aires: A population-based study
}

\author{
Ángela Gentile, M.D. ${ }^{a}$, Julia Bakir, M.D. ${ }^{a}$, Laura Bialorus, M.D. ${ }^{b}$, \\ Laura Caruso, M.D. ${ }^{c}$, Diego Mirra, M.D. ${ }^{b}$, Celina Santander, Biochemist ${ }^{b}$, \\ Mabel Terluk, M.D. ${ }^{b}$, Pablo Zurdo, M.D. ${ }^{b}$, Fernando Gentile, M.D. ${ }^{a}$, \\ and María I. Fernández, M.D. ${ }^{b}$
}

\begin{abstract}
Introduction. In January 2012, Argentina introduced the 13-valent pneumococcal conjugate vaccine (PCV13) in its immunization schedule for children younger than 2 years old. Coverage in Pilar in 2012 reached $>90 \%$ for the first two doses and $60 \%$ for the third dose.

Objective. To measure the effectiveness of PCV13 to reduce the incidence of consolidated pneumonia $(\mathrm{CP})$ in the two-year period following its introduction in the immunization schedule. Methods. Prospective, population-based study conducted in Pilar. All children younger than 5 year sold with clinical signs of pneumonia assisted at the reference hospitals (bothinpatients and utpatients) in the first two years since the vaccine introduction (2012-2013) were included. The annual incidence of CP was compared to the 2003-2005 baseline period. Clinical and radiological assessments were done as per the World Health Organization's criteria.

Results. Six hundred and sixty-six patients with clinical suspicion of pneumonia were included. $\mathrm{CP}$ was diagnosed in 309 patients; $52.1 \%$ were girls, $70.2 \%$ were younger than 2 years old, and $56.4 \%$ had been immunized with the PCV13; $4.5 \%(14 / 309)$ had bacteriological confirmation (S. pneumoniae: $4 ;$ N. meningitidis: $4 ;$ S. aureus: 2 ; others:4). A significant reduction in theincidence of $\mathrm{CP}$ (per 100000 children younger than 5 years old) was observed between the pre- and postimmunization periods, from $750(204 / 27209)$ to $561(171 / 30475)$ in 2012 and to $453(138 / 30475)$ in 2013; effectiveness accounted for $25.2 \%$ and $39.6 \%$,respectively. Reduction in infants younger than 1 year old: $33.9 \%$ in 2012 and $44.6 \%$ in 2013; and in children aged $12-23$ months old: $57.9 \%$ in 2013. No significant differences were observed in the incidence of $\mathrm{CP}$ at an older age.

Conclusions. Following the introduction of PCV13 in Argentina's immunization schedule, a fast and significant reduction in the incidence of $\mathrm{CP}$ was observed, mainly in infants younger than 1 year old in 2012 and in children younger than 2 years old in 2013.

Key words: Streptococcus pneumoniae, pneumonia, conjugate vaccine, effectiveness, child.
\end{abstract}

http:/ /dx.doi.org/10.5546/aap.2015.eng.502

\section{INTRODUCTION}

Streptococcus pneumoniae is the main bacterial cause of communityacquired pneumonia (CAP); however, establishing the burden of pneumococcal pneumonia accurately is difficult given that routine diagnostic tests have a low sensitivity. Microorganisms are isolated in the blood of less than $10 \%$ of patients hospitalized for CAP, and culture performance is greater when patients have empyema and there is a sample of pleural fluid available. ${ }^{1}$ Therefore, it is evident that microbiological diagnosis provides a very partial account of the impact of S. pneumoniae.

Due to such difficulties, the World Health Organization (WHO) developed a protocol based on the standardized interpretation of chest $\mathrm{x}$-rays. The WHO proposed to measure vaccine effectiveness based on the reduction in "radiologicallyconfirmed consolidated pneumonia" as a reasonable approach to "bacterial pneumonia". The purpose was strictly epidemiological in order to provide an effective tool that would allow measuring the impact of introducing conjugate pneumococcal vaccines in national immunization schedules. ${ }^{2}$

In Argentina, a prospective, population-based study was conducted in Pilar between 2003 and 2005 (3-year period), that allowed to establish baseline data regarding the burden of consolidated pneumonia $(\mathrm{CP})$ in children $<5$ years old, which accounted for an average of 750 cases per 100000 (95\% confidence interval 
[CI]: 650-860), and 1922 per 100000 in infants younger than 1 year old (95\% CI: 1560-2330). ${ }^{3}$

In January 2012, the 13-valent pneumococcal conjugate vaccine (PCV13) was introduced in the national immunization schedule as of two months old, with a " $2+1$ " schedule (one dose at 2 months old, another dose at 4 months old, and a booster dose at 1 year old). During the first year after introducing the vaccine, children aged between 12 and 24 months old were also immunized with two doses in order to achieve a greater impact on the reduction of invasive pneumococcal disease in the shortest period possible in Argentina. ${ }^{4}$ The national coverage of PCV13 for 2012 was $69 \%$ for the first dose and $22 \%$ for the third dose, while in 2013, it accounted for $96 \%$ and $81 \%$, respectively. ${ }^{5}$ Coverage in the district of Pilar was estimated using nominal records and accounted for $100 \%, 83 \%$ and $48.3 \%$ for the first, second and third doses, respectively, out of a total of 6735 live newborn infants in $2012 .^{6}$ In 2013 , coverage accounted for $87.6 \%, 84.9 \%$ and $61.3 \%$, respectively. ${ }^{7}$

\section{OBJECTIVE}

To measure the effectiveness of PCV13 to reduce consolidated pneumonia in the two-year period following its introduction in the national immunization schedule.

\section{METHODS Population}

Pilar is located $54 \mathrm{~km}$ to the northwest of the province of Buenos Aires and, according to the 2010 National Population Census; it has 299077 inhabitants, and 30475 (10.2\%) are younger than 5 years old. The latter made up the follow-up population.

\section{Inclusion criteria}

All children $<5$ years old with clinical signs of pneumonia were assisted either as inpatients or outpatients between January 1st, 2012 and December 31st, 2013 at the reference hospitals located in Pilar (two public hospitals: Hospital de Niños Federico Falcón, Hospital Juan Sanguinetti; and a private hospital: Hospital Universitario Austral). The algorithm in Figure 1 shows how consolidated pneumonia was diagnosed.

\section{Exclusion criteria}

Patients with nosocomial pneumonia were excluded; as per the WHO, this is defined as pneumonia that had neither developed nor was in the incubation period, i.e., it was acquired during hospitalization and is not the reason for hospitalization. ${ }^{8}$

Operational algorithm

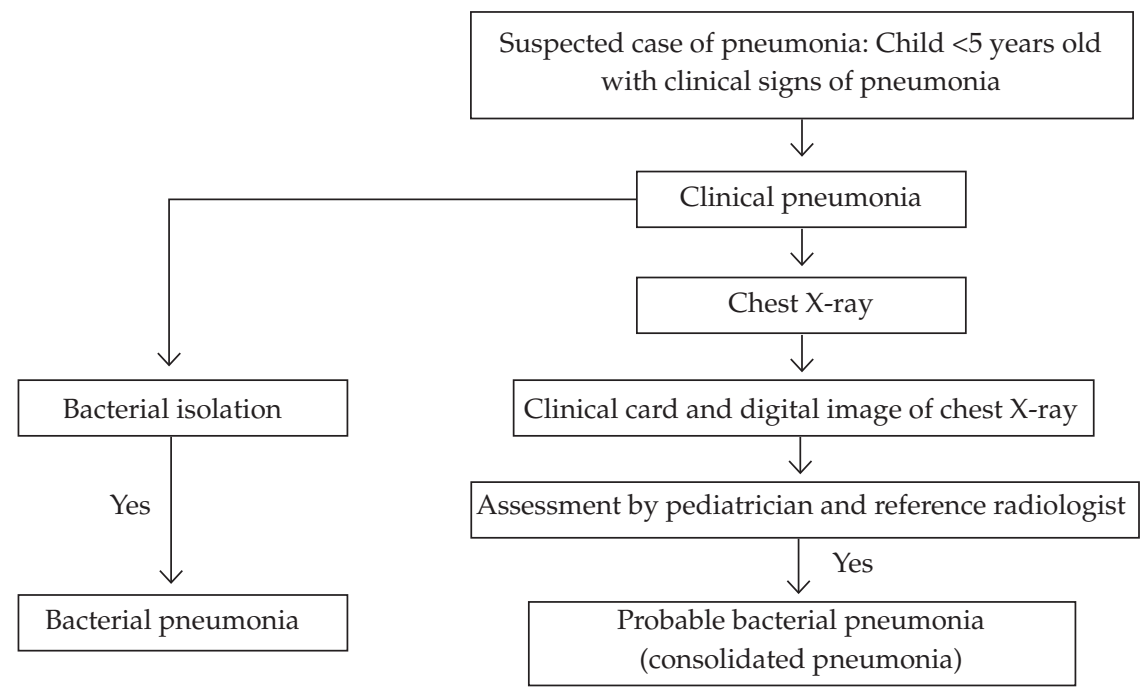




\section{Design}

Prospective, population-based study conducted following the introduction of PCV13 in 2012 in the national immunization schedule.

\section{Data collection}

Data were obtained from medical records of patients assisted either as inpatients or outpatients who complied with inclusion criteria. Relevant data were summarized in a standard card and included age, sex, socioeconomic level as per Graffar's modified method, ${ }^{9}$ history of pneumococcal immunization (type of vaccine and number of doses), cohabitation with five or more people in the same house and with more than three people in the same room, prior hospitalizations, perinatal history, presence of underlying diseases, antibiotic treatment in the three previous months and in the week prior to hospitalization, selected respiratory signs and symptoms, complications, treatment and course.

Underlying diseases were defined as those indicated in the national recommendations for pneumococcal immunization in special hosts. ${ }^{10}$ In addition, other risk conditions were studied, such as second-hand smoking and acute respiratory disease in the previous week.

Complications were defined as effusion, pneumothorax, atelectasis, necrotizing pneumonia, abscess, and respiratory failure.

\section{Microbiological study}

A microbiological study was conducted only in hospitalized patients. Bacterial etiology was studied in blood and/or pleural fluid. Pleural tap was performed when thoraco centesis was therapeutically indicated.

Isolations of S. pneumoniae were submitted to the National Infectious Disease Institute (Instituto Nacional de Enfermedades Infecciosas, INEI),
National Administration of Health Institutes and Labs (Administración Nacional de Laboratorios e Institutos de Salud, ANLIS) "Dr. Carlos G. Malbrán" in order to confirm identification and serotyping by means of the Quellungreaction. Antimicrobial susceptibility was studied using the agar diffusion method and the minimum inhibitory concentration (MIC), established by means of broth or agar micro dilution method or E-test, according to the current standards of the Clinical Laboratory Standards Institute (CLSI). ${ }^{11}$

Viral etiology was studied as per the treating pediatrician's clinical judgment. The indirect immunofluorescence (IIF) rapid diagnostic method was used for nasopharyngeal aspirates to look for the following respiratory viruses: respiratory syncytial virus (RSV), adenovirus, influenza A and B, and para influenza 1,2 and 3.

\section{Radiological assessment}

Chest X-rays were captured in digital images and were interpreted by the investigator pediatrician and the reference radiologist in a blinded and independent manner as per the WHO methodology. Discrepancies were resolved through a third reading.

\section{Definition of consolidated pneumonia}

Pneumonia with dense opacity and cotton wool-like appearance (alveolar infiltrate), involving one or more segments or lung lobes, or an entire lung. It usually presents with an air broncho gram, and sometimes in association with pleural effusion.

\section{Data analysis}

Statistical analysis was done using the Epi Info software, version 6.4 (CDC, Atlanta), and the Epidat software, version 3.1.

Qualitative outcome measures were expressed

TABLE 1. Studied population: comparison of pre-and post-introduction of the 13-valent pneumococcalconjugate vaccine

\begin{tabular}{|c|c|c|c|c|}
\hline \multirow[t]{2}{*}{ Population included as per the algorithm } & \multicolumn{2}{|c|}{$\begin{array}{l}\text { Pre-PCV13 period } \\
(2003-2005)\end{array}$} & \multicolumn{2}{|c|}{$\begin{array}{l}\text { Post-PCV13 period } \\
\qquad(2012-2013)\end{array}$} \\
\hline & $\mathbf{n}$ & $\%$ & $\mathbf{n}$ & $\%$ \\
\hline Total number of patients with clinical suspicion of pneumonia & 1220 & 100.0 & 666 & 100.0 \\
\hline Suspected cases of pneumonia with digital images of chest X-ray & 1108 & 90.8 & 642 & 96.4 \\
\hline Cases of consolidated pneumonia & 611 & 55.1 & 309 & 48.1 \\
\hline Cases of bacterial consolidated pneumonia & 15 & 2.5 & 14 & 4.5 \\
\hline Cases of pneumococcal consolidated pneumonia & 7 & 1.2 & $4^{*}$ & 1.3 \\
\hline
\end{tabular}

PCV13: 13-valent pneumococcal conjugate vaccine.

No significant differences between both periods.

*2012: $n=2$; and 2013: $n=2$. 
in terms of percentage and analyzed using a $\chi^{2}$ test with Yates' correction. Numerical outcome measures were described using mean value, standard deviation (SD), median and range.

The annual incidence of CP cases and the average annual incidence in the pre-immunization period with a $95 \%$ CI were estimated. The difference between pre-immunization and postimmunization incidence were expressed as effectiveness and estimating the percentage of reduction with a $95 \% \mathrm{CI}$.

A probability lower than 0.05 was considered significant.

\section{Ethical aspects}

No informed consent was requested for this research because it was a surveillance study. This study was approved by the Research Ethics Committee of participating hospitals.

\section{RESULTS}

During the two-year period following the introduction of the PCV13, 666 patients with clinical suspicion of pneumonia were included.

Of all X-rays, $96.4 \%(642 / 666)$ were photographed, and CP was diagnosed in $48.1 \%$ (309/642). Table 1 shows the population included in this period and in the pre-PCV13 period.

\section{Description of the population of patients with consolidated pneumonia}

In the population of patients with $\mathrm{CP}(\mathrm{n}=309)$, the median age was 13 months old (range: 0-59 months old); $70.2 \%$ were younger than 2 years old $(47.6 \%$ of these were younger than 1 year old).

Out of children younger than 2 years old who attended the visit with their vaccination card, $62.9 \%(107 / 170)$ had received the PCV13; $43.9 \%$ (47/107) had received one dose, $42.6 \%$

TABLE 2. Characteristics of the population with consolidated pneumonia: comparison of pre-and post-introduction of the 13-valent pneumococcal conjugate vaccine

\begin{tabular}{|c|c|c|c|c|c|c|}
\hline \multirow[t]{2}{*}{ Characteristics } & & \multicolumn{2}{|c|}{$\begin{array}{l}\text { Pre-PCV13 period } \\
2003-2005(n=611)\end{array}$} & \multicolumn{2}{|c|}{$\begin{array}{l}\text { Post-PCV13 period } \\
2012-2013(n=309)\end{array}$} & \multirow[t]{2}{*}{$\mathbf{p}$} \\
\hline & & $\mathbf{n}$ & $\%$ & $\mathbf{n}$ & $\%$ & \\
\hline Type of care & $\begin{array}{l}\text { Outpatient } \\
\text { Inpatient }\end{array}$ & $\begin{array}{l}139 \\
472\end{array}$ & $\begin{array}{l}22.7 \\
77.3\end{array}$ & $\begin{array}{c}84 \\
225\end{array}$ & $\begin{array}{l}27.2 \\
72.8\end{array}$ & NS \\
\hline Sex & Male & 337 & 55.2 & 148 & 47.9 & 0.04 \\
\hline Age & $\begin{array}{l}0-23 \text { months old } \\
24-59 \text { months old }\end{array}$ & $\begin{array}{l}448 \\
163\end{array}$ & $\begin{array}{l}73.3 \\
26.7\end{array}$ & $\begin{array}{c}217 \\
92\end{array}$ & $\begin{array}{l}70.2 \\
29.8\end{array}$ & NS \\
\hline Socioeconomic level & $\begin{array}{l}\text { High } \\
\text { Middle } \\
\text { Low }\end{array}$ & \multicolumn{2}{|c|}{ NA } & $\begin{array}{c}63 \\
181 \\
65\end{array}$ & $\begin{array}{l}20.4 \\
58.6 \\
21.0\end{array}$ & \\
\hline \multicolumn{2}{|c|}{ More than five people living in the house } & \multicolumn{2}{|c|}{ NA } & 108 & 35.0 & \\
\hline \multicolumn{2}{|c|}{ More than three people in the same room } & \multicolumn{2}{|c|}{ NA } & 50 & 16.2 & \\
\hline \multicolumn{2}{|l|}{ Underlying disease } & 284 & 46.5 & 182 & 58.9 & $<0.01$ \\
\hline \multicolumn{2}{|c|}{ Chronic or recurrent respiratory disease } & 214 & 35.0 & 130 & 42.1 & 0.04 \\
\hline \multicolumn{2}{|l|}{ Malnutrition } & 31 & 5.1 & 8 & 2.6 & NS \\
\hline \multicolumn{2}{|l|}{ History of prematurity } & \multicolumn{2}{|c|}{ NA } & 40 & 12.9 & \\
\hline Prior antibiotic use & $\begin{array}{l}\text { In the three previous months } \\
\text { In the previous week }\end{array}$ & $\begin{array}{l}69 \\
47\end{array}$ & $\begin{array}{l}11.3 \\
7.7\end{array}$ & $\begin{array}{l}34 \\
18\end{array}$ & $\begin{array}{l}11.0 \\
5.8\end{array}$ & $\begin{array}{l}\text { NS } \\
\text { NS }\end{array}$ \\
\hline \multicolumn{2}{|l|}{ Prior hospitalizations } & 143 & 23.4 & 84 & 27.2 & NS \\
\hline \multicolumn{2}{|c|}{ Acute respiratory disease in the previous week } & \multicolumn{2}{|c|}{ NA } & 52 & 16.8 & \\
\hline \multicolumn{2}{|l|}{ Second-hand smoking } & \multicolumn{2}{|c|}{ NA } & 127 & 41.1 & \\
\hline Symptoms & $\begin{array}{l}\text { Cough } \\
\text { Fever } \\
\text { Tachypnea } \\
\text { Intercostal retraction retraction } \\
\text { Respiratory distress } \\
\text { Difficulty feeding } \\
\text { Wheezing } \\
\text { Vomiting } \\
\text { Cyanosis }\end{array}$ & $\begin{array}{l}605 \\
485 \\
593\end{array}$ & $\begin{array}{l}99.0 \\
79.4 \\
97.0\end{array}$ & $\begin{array}{l}284 \\
277 \\
251 \\
135 \\
238 \\
132 \\
94 \\
72 \\
61\end{array}$ & $\begin{array}{l}91.9 \\
89.6 \\
81.2 \\
43.7 \\
77.0 \\
42.7 \\
30.4 \\
23.3 \\
19.7\end{array}$ & $\begin{array}{l}<0.01 \\
<0.01 \\
<0.01\end{array}$ \\
\hline
\end{tabular}

NS: not significant difference. NA: not assessed.

PCV13: 13-valent pneumococcal conjugate vaccine. 
(42/107), two doses, and 16.8\% (18/107), three doses. Seven patients had received the PCV7 before the introduction of the PCV13 in the immunization schedule. In general, no significant differences were observed in the characteristics of the population of patients with $\mathrm{CP}$ that were assessed between both periods (Table 2).

\section{Symptoms and clinical course}

\section{of patients with consolidated pneumonia}

The most common symptoms of patients with $\mathrm{CP}$ were cough, fever and tachypnea, like what was observed in the pre-PCV13 period, but there were significant differences (Table 2). Out of patients hospitalized for CP, $26.7 \%(60 / 225)$ had the following complications, by order of frequency (out of a total of 78 complications recorded): effusion $(38.5 \%)$, respiratory failure $(25.6 \%)$, atelectasis $(15.4 \%)$, pneumothorax / bullae (11.5\%), necrotizing pneumonia (5.1\%), and lung abscess (3.9\%); lethality accounted for $0.9 \%(2 / 225)$.

\section{Microbiological diagnosis}

Bacteriological tests were performed in $99.6 \%$ of patients hospitalized for CP $(224 / 225)$.

All had blood cultures done, and four had pleural fluid cultures. Bacterial etiology was identified in 14 patients (6.3\%): S. pneumoniae (4), S. aureus (2), N. meningitidis (4) and other microorganisms in four patients, which resulted in a rate of confirmed bacterial CP of $4.5 \%$ $(14 / 309)$.

S. pneumoniae $(\mathrm{n}=4)$ serotypes included $23 \mathrm{~F}, 4,7 \mathrm{~F}$ (all included in the vaccine), and one partial serotype: 27,32 or 41 (infections caused by these serotypes corresponded to two non-vaccinated patients and two with an incomplete immunization schedule for their age at $<12$ months old). All S. pneumonia strains were sensitive to penicillin.

Only 51 patients hospitalized for CP had an IIF performed using nasopharyngeal aspirates; 34 were positive (66.7\%): RSV (73.5\%), parainfluenza virus $(14.7 \%)$, adenovirus (5.9\%), and influenza virus $(5.9 \%)$. Two patients had mixed infections (one had S. pneumoniae plus RSV and one had S. agalactiae plus RSV).

\section{Impact of the 13-valent pneumococcal conjugate vaccine}

A significant reduction in the incidence of $\mathrm{CP}$ (per 100000 children $<5$ years old) was observed following the introduction of the PCV13 when compared to the pre-vaccine reference period. When adjusted by age, a greater reduction was observed among infants younger than 12 months old in 2012, which was even greater in 2013, while the 12-23 month-old group showed a significant reduction only in 2013, the second year after the intervention was implemented (Table 3).

No significant differences were observed in the incidence of $\mathrm{CP}$ at an older age.

\section{DISCUSSION}

In Argentina, according to the latest report by the Ministry of Health (December 2012), respiratory disease was the third cause of child mortality (after perinatal conditions and congenital anomalies) and accounted for $8.6 \%$ of all deaths in this period, which stood for 764 children younger than 5 years old deceased in $2011 .^{12}$

TABLE 3. Incidence of consolidated pneumonia by age group. Effectiveness of the 13-valent pneumococcal conjugate vaccine

\begin{tabular}{|c|c|c|c|c|c|c|c|c|c|c|}
\hline \multirow[t]{4}{*}{ Age groups } & \multirow{2}{*}{\multicolumn{3}{|c|}{$\begin{array}{c}\text { Pre-PCV13 period } \\
2003-2005\end{array}$}} & \multicolumn{7}{|c|}{ Post-immunization period } \\
\hline & & & & & & 2012 & & & 20 & 13 \\
\hline & \multirow{2}{*}{$\begin{array}{l}\text { Population } \\
\text { at risk }^{\mathrm{a}}\end{array}$} & $\mathrm{n}$ & Incidence $^{\mathrm{b}}$ & \multirow{2}{*}{$\begin{array}{c}\text { Population } \\
\text { at risk }\end{array}$} & \multirow{2}{*}{$n$} & \multirow{2}{*}{$\begin{array}{c}\text { Incidence }^{\mathrm{b}} \\
(95 \% \text { IC })\end{array}$} & \multirow{2}{*}{$\begin{array}{c}\text { Effectiveness } \\
\%(95 \% \text { IC) }\end{array}$} & \multirow[t]{2}{*}{$\mathrm{n}$} & \multirow{2}{*}{$\begin{array}{c}\text { Incidence }^{\mathrm{b}} \\
(95 \% \mathrm{IC})\end{array}$} & \multirow{2}{*}{$\begin{array}{c}\text { Effectiveness } \\
\%(95 \% \text { IC) }\end{array}$} \\
\hline & & & erage $(95 \% \mathrm{IC})$ & & & & & & & \\
\hline \multicolumn{11}{|l|}{ Younger than } \\
\hline 5 years old & 27209 & 204 & $750(650-860)$ & 30475 & 171 & $561(480-650)$ & $25.2(8.3-38.9)$ & 138 & $453(380-530)$ & $39.6(25.0-51.3)$ \\
\hline 0-11 months old & 5324 & 102 & $1922(1560-2330)$ & 6314 & 80 & $1267(1000-1580)$ & $33.9(11.6-50.5)$ & 67 & $1061(820-1350)$ & $44.6(24.6-59.3)$ \\
\hline 12-23 months old & 5046 & 47 & $931(680-1240)$ & 6113 & 46 & $752(550-1000)$ & $19.2(\mathrm{NS})$ & 24 & $393(250-580)$ & $57.9(31.1-74.2)$ \\
\hline 24-59 months old & 16839 & 54 & $321(240-420)$ & 18048 & 45 & $249(180-330)$ & 22.3 (NS) & 47 & $260(190-350)$ & $18.8(\mathrm{NS})$ \\
\hline
\end{tabular}

a 2000 Census.

${ }^{\mathrm{b}}$ Incidence per 100000 individuals/year.

c 2010 Census.

NS: not significant difference.

PCV13: 13-valent pneumococcal conjugate vaccine. 
Pneumonia, one of the forms of pneumococcal disease, caused almost one in every five deaths in children younger than 5 years old worldwide: more than 1.6 million children per year, as per the estimations based on data for $2000 .{ }^{13}$ Reducing mortality associated with $S$. pneumonia is critical if the international community wishes to reach the Millennium Development Goals (MDG), especially MDG 4 (to reduce child mortality worldwide). The WHO's official stance is that immunization against pneumococcal disease should be a priority and implemented in all national immunization schedules, especially in those countries with a high rate of child mortality.

In the case of pneumococcal disease, conjugate vaccines provide immunity against $S$. pneumoniae in infants and toddlers and may confer an indirect protection to community individuals who are not immune (including non-vaccinated children) through "community immunity" or the "herd effect", which reduces the transmission of the infectious agent by immunized individuals.

As of the end of the 1990s, several studies on the incidence of CAP were conducted in Latin American countries, which have been used as baseline to measure the effectiveness of this intervention in the corresponding countries. The studies conducted in Uruguay, Brazil and Argentina demonstrated similar results in terms of CP incidence. ${ }^{3,14-16}$

Data from Pilar were used as baseline in this study to measure the importance of the intervention in the post-vaccine period.

When the available characteristics of the studied population are analyzed as per pre- and post-intervention, no statistically significant differences are observed, in spite of the years elapsed; therefore, there are no biases in the type of studied population. However, the geographic location of the area under surveillance may be considered a weakness of this study: the population of Pilar is very close to the City of Buenos Aires and some children may have been assisted outside Pilar; therefore, the incidence rate indicated here may be lower than the actual rate. This applies to both study periods: pre- and postintroduction of the 13-valent conjugate vaccine, therefore, results are not overridden.

The symptoms that motivated the consultation of children included in the study (cough, fever and tachypnea) are common in this type of pathology, a triad of symptoms usually recognized by pediatricians, found in every publication on this topic and that depicts the severity of these patients at the time of clinical assessment. ${ }^{1,17,18}$

Although the etiologic agent was tested in all hospitalized patients by means of blood and/or pleural fluid cultures, it is worth noting that retrieval was low: bacterial etiology was documented only in $4.5 \%$. This allows once again to reflect on the importance of an alternative indicator, the incidence of consolidated pneumonia, proposed by the $\mathrm{WHO} /$ Pan American Health Organization (PAHO) to measure the effectiveness of conjugate pneumococcal vaccines for the prevention of pneumonia. ${ }^{2}$

Another element that is worth noting is the role of viruses in the etiology of consolidated pneumonia. Only $22.7 \%$ of patients hospitalized for $\mathrm{CP}$ were studied due to programmatic difficulties; this may be considered a weakness of this study. However, these data highlight the importance of the role of SRV in the etiology of these clinical forms.${ }^{19}$ Studies found in the international and Latin American bibliography have also demonstrated the role of influenza virus in the etiology of these clinical forms. ${ }^{14,20,21}$ Further investigations are required on cases of viral and bacterial co-infection.

Effectiveness data show an important reduction in the extent of this disease: the incidence of consolidated pneumonia reduced by $33.9 \%$ and $44.6 \%$ in infants younger than one year old in 2012 and 2013, respectively. Essentially, the reason for this is that immunization coverage in Pilar was very high in this age group: it reached more than $80 \%$ for the first two doses.

This effect is observed in the 1-2 year-old group in the second year of the study and is directly related to the level of coverage reached in this area. Since these percentages are not as high as they were supposed to be, the "herd effect" is yet to be seen in children older than 2 years old. Such effect of the pneumococcal conjugate vaccine in children who did not receive the vaccine as part of the regular schedule or whose age is not covered by the vaccine would lead to an even higher reduction if coverage was above $80 \%$ in the target population. ${ }^{4}$

Studies conducted by Hortal and Andrade in Uruguay and Brazil, respectively, show similar results. In Uruguay, the incidence of consolidated pneumonia in the 12-23 month-old group reduced by $44.9 \%$ with a methodology similar to the one used in the district of Pilar, with a coverage provided by the 13-valent pneumococcal vaccine of approximately $92 \%{ }^{22}$

In Brazil, the 10-valent pneumococcal 
conjugate vaccine (pneumococcal non type able Haemophilus influenzae protein D conjugate vaccine, PHiD_CV) showed a significant reduction in pneumonia in Belo Horizonte $(28.7 \%)$, Curitiba $(23.3 \%)$ and Recife $(27.4 \%)$, but this was not the case in San Pablo and Porto Alegre, where reduction was not significant, possibly because immunization coverage were not as high. ${ }^{23}$

It is important to conduct epidemiological research in Argentina with our own data in order to measure implemented actions and adjust strategies as per local data. In addition, sharing the information generated and analyzed in one area of Argentina may encourage other sites and jurisdictions to perform local analyses as well.

\section{CONCLUSION}

Following the introduction of PCV13 in Argentina's immunization schedule, a fast and significant reduction in the incidence of consolidated pneumonia was observed, mainly in infants younger than 1 year old in 2012 (year of vaccine introduction), and that extended to the entire group of children younger than 2 years old in 2013.

\section{REFERENCES}

1. Comité de Infecciones Respiratorias de la Sociedad Latinoamericana de Infectología Pediátrica (SLIPE). Consenso de la SLIPE sobre Neumonía Adquirida en la Comunidad (NAC). Rev Enfer Infec Pediatr 2010;24(94):3-23. [Accessed on:February 17, 2014]. Availableat:http:/ /www. slipe.org/pdf/ConsensoNACninosSLIPE_8sept2010.pdf.

2. World Health Organization Pneumonia Vaccine Trial Investigators' Group. Department of Vaccines and Biologicals. Standardization of interpretation of chestradiographs for the diagnosis of pneumonia in children. Geneva, 2001. [Accessed on: Wednesday, July 01, 2015]. Available at: http:/ / whqlibdoc.who.int/hq/2001/ WHO_V\&B_01.35.pdf.

3. Gentile A, Ruvinsky R, Bakir J, Gentile F, et al. Surveillance of Probably Bacterial Pneumonia in children less than 5 years old in two geographical areas in Argentina. Abstract of the 45th Interscience Conference on Antimicrobial Agents and Chemotherapy. Washington DC, 2005; G-822 236.

4. Argentina. Ministerio de Salud. Introducción de la Vacuna Conjugada contra el Neumococo al Calendario Nacional de Inmunizaciones de la República Argentina. Lineamientos Técnicos y Manual del Vacunador. Buenos Aires: Ministerio de Salud de la Nación, 2011. [Accessed on: Wednesday, July 01, 2015]. Available at: http:/ / www. msal.gov.ar/neumococo/ descargas/lineamientosneumococo-25-11-2011.pdf.

5. WHO. WHO vaccine-preventable diseases: monitoring system. 2015 global summary Coverage time series for Argentina. [Accessed on:Sunday, March 01,2015]. Available at: http://apps.who.int/immunization_monitoring/ globalsummary / coverages?c=ARG.

6. Programa de Inmunizaciones. Dirección de Epidemiología.
Dirección de Medicina Preventiva. Ministerio de Salud de la Provincia de Buenos Aires Partido de Pilar. Secretaría de Salud. Cobertura de vacuna neumocócica conjugada 13 valente, 2012 (comunicación personal).

7. Dirección Provincial de Medicina Preventiva Región Sanitaria V Área Epidemiología. Ministerio de Salud de la Provincia de Buenos Aires. Cobertura de vacunación en menores de un año, Prevenar 13, según municipios. Año 2013. Boletín Epidemiológico 2013. p 52.

8. Organización Mundial de la Salud. Prevención de las infecciones nosocomiales. Guía Práctica. 2. ${ }^{\text {a }}$ ed. Malta, 2003. [Accessed on: Sunday, April 12, 2015]. Available at: http:/ / www.who.int/csr/resources/publications/ES_ WHO_CDS_CSR_EPH_2002_12.pdf.

9. Méndez Castellano H. Sociedad y Estratificación: Método Graffar-Méndez Castellano. Caracas: FUNDACREDESA; 1994.

10. Argentina. Ministerio de Salud. Recomendaciones Nacionales de Vacunación, Argentina 2012. Buenos Aires, 2012. [Accessed on: Wednesday, July 01, 2015]. Available at: http://www.msal.gov.ar/images/stories/ bes/graficos/0000000451cnt-2013-06_recomendacionesvacunacion-argentina-2012.pdf.

11. Clinical and Laboratory Standards Institute. Performance Standards for Antimicrobial Susceptibility Testing; Nineteenth InformationalSupplement(M100-S19). Wayne, PA; 2009.

12. Argentina. Ministerio de Salud. Secretaría de Políticas, Regulación e Institutos, Dirección de Estadísticas e Información de Salud. Sistema Estadístico de Salud. Estadísticas vitales. Información básica año 2011. Buenos Aires, 2012;5(55). [Accessed on: Wednesday, July 01, 2015]. Availableat:http://www.deis.msal.gov.ar/Publicaciones/ Archivos/Serie5Nro57.pdf.

13. World Health Organization. UNICEF. Global action plan for prevention and control of pneumonia (GAPP). [Accessed on: Wednesday, July 01, 2015]. Available at: http:/ / whqlibdoc.who.int/hq/2009/WHO_FCH_CAH_ NCH_09.04_eng.pdf?ua=1.

14. Hortal M, Estevan M, Iraola I, De Mucio B. A populationbased assessment of the disease burden of consolidated pneumonia in hospitalized children under five years of age. Int J Infect Dis 2007;11(3):273-7.

15. Andrade AL, Silva SA, Martelli CM, Oliveira RM, et al. Population-based surveillance of pediatric pneumonia: use of spatial analysis in an urban area of Central Brazil. Cad Saude Publica 2004;20(2):411-21.

16. Tregnaghi M, Ceballos A, Rüttimann R, Ussher J, et al. Active epidemiologic surveillance of pneumonia and invasive pneumococcal disease in ambulatory and hospitalized infants in Córdoba, Argentina. Pediatr Infect Dis J 2006;25(4):370-2.

17. Pírez MC, Algorta G, Cedrés A, Sobrero H, et al. Impact of universal pneumococcal vaccination on hospitalizations for pneumonia and meningitis in children in Montevideo, Uruguay. Pediatr Infect Dis J 2011;30(8):669-74.

18. Sociedad Argentina de Pediatría. Comité de Infectología Pediátrica. Libro Azul de Infectología Pediátrica. 4.a ed. Buenos Aires: FUNDASAP; 2012:413-7.

19. Lución MF, Juárez MV, Viegas M, Castellano V, et al. Virus respiratorio sincicial. Patrón clínico epidemiológico en niños internados en un hospital pediátrico durante los años 2000-2013. Arch Argent Pediatr 2014;112(5):397-404.

20. Gentile A, Bakir J, Russ C, Ruvinsky S, et al. Estudio de las enfermedades respiratorias por virus Influenza A H1N1 (pH1N1) en niños internados durante el año de la pandemia. Experiencia de 34 centros en la Argentina. Arch 
Argent Pediatr 2011;109(3):198-203.

21. Juárez MV, Lución MF, BakirJ, Romanin V, etal. Efectividad de la vacuna neumocócica de 13 serotipos en menores de 5 años a través de la vigilancia epidemiológica de las neumonías consolidantes y la influencia de los virus respiratorios. Estudio de series temporales 2001-2013. 7. ${ }^{\circ}$ Congreso Argentino de Infectología Pediátrica; 2014, abril 3-5. Córdoba: Sociedad Argentina de Pediatría, 2014. Abstract PO52. p. 78.
22. HortalM,Estevan M,LauraniH,Iraola I,MenyM,Paysandú/ Salto Study Group. Hospitalized children with pneumonia in Uruguay: pre and post introduction of 7 and 13-valent pneumococcal conjugated vaccines into the National Immunization Program. Vaccine 2012;30(33):4934-8.

23. Andrade AL, Oliveira R, Vieira MA, Minamisava R, et al. Population-based surveillance for invasive pneumococcal disease and pneumonia in infants and young children in Goiania, Brazil. Vaccine 2012;30(10):1901-9. 